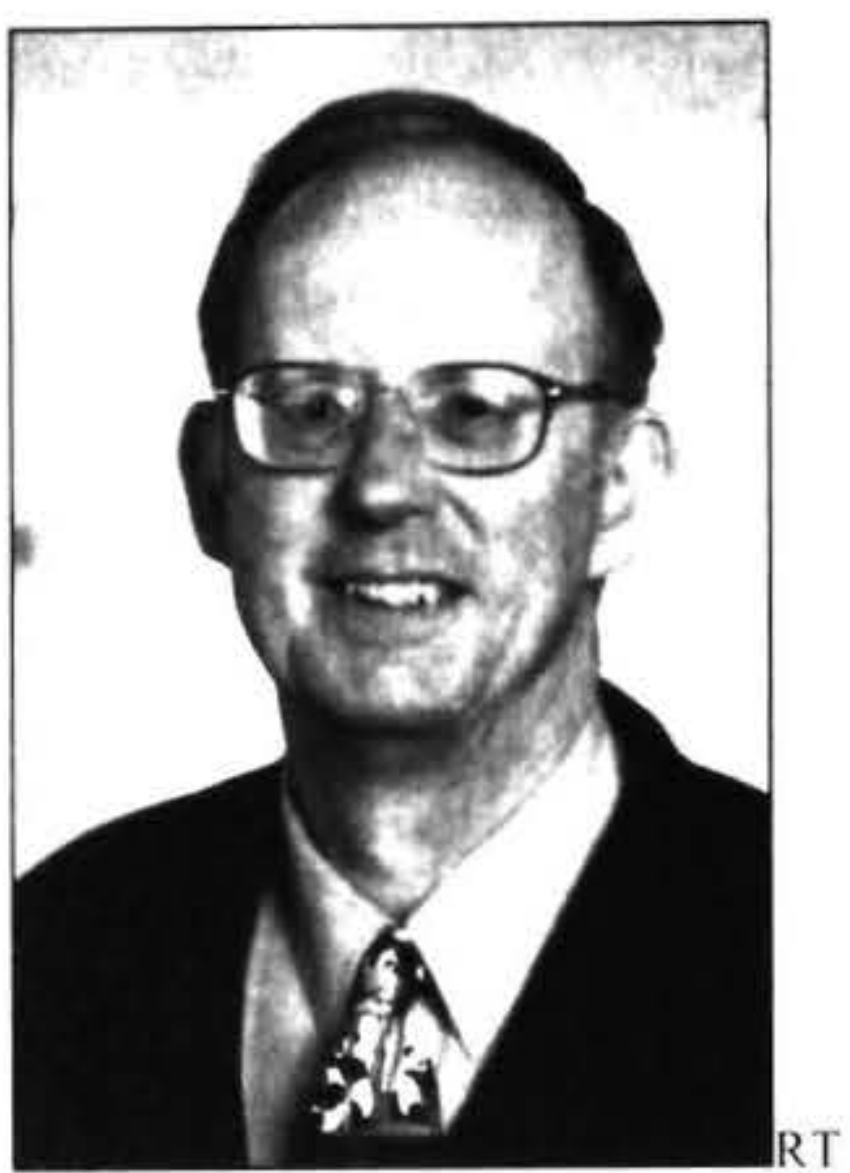

\title{
EMPLOYMENT RELATIONSHIPS IN DAIRY FARMING - PSYCHOLOGICAL CONTRACTS RECONSIDERED ${ }^{\prime}$
}

\author{
Rupert Tipples \\ Agriculture and Life Sciences Division, \\ Lincoln University.
}

Nona Verwoerd

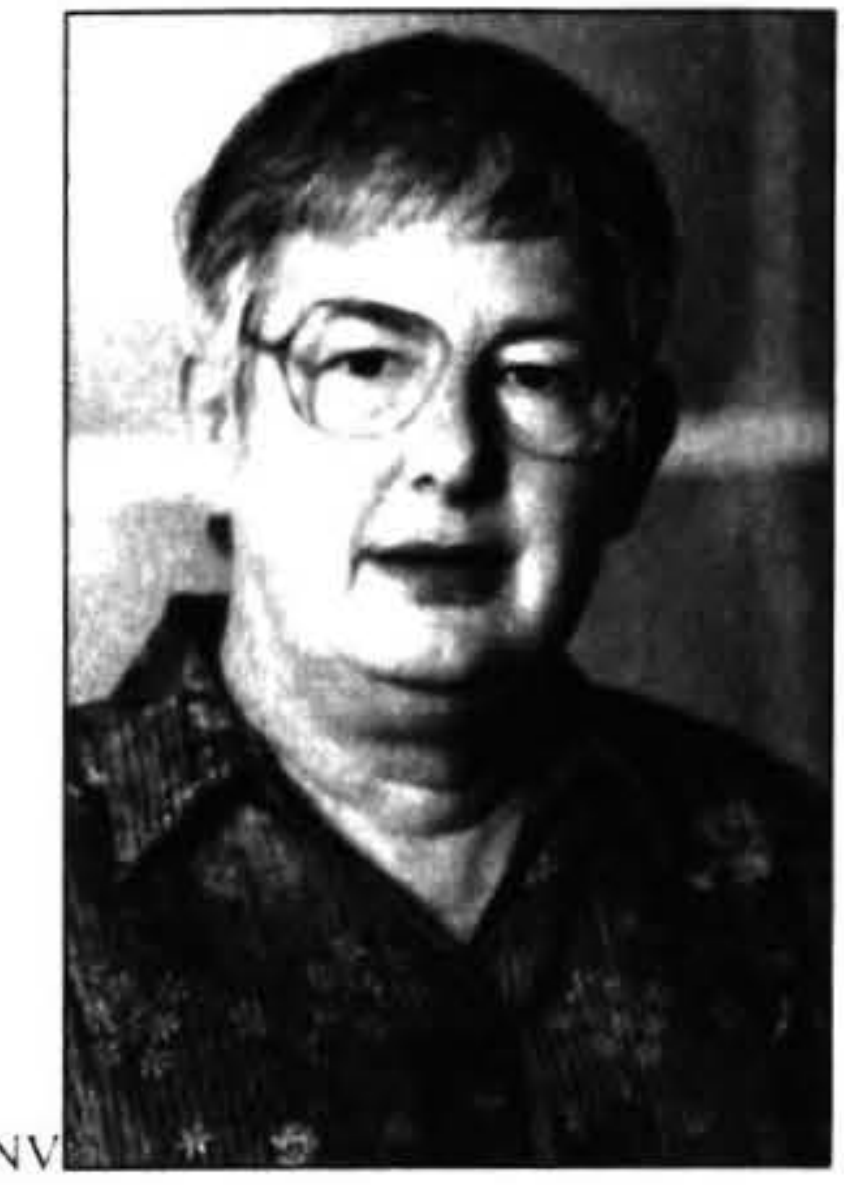

Independent Consultant and Researcher.

\begin{abstract}
The essence of psichological contracting (in the context of employment) is meeting mutual expectations. The common denominator between legal contracting and psichological contracting is that hoth are designed to express expectations of the self and of the other. Legal expectations lead to outcomes that are observable, measurable and usually quantifiable. Psichological expectations are usually invisible hut nonetheless verv real.
\end{abstract}

This paper expresses the need for greater attention to psychological contracting in a dairy sector going through suhstantial structural change involving the replacement of self employed farmers hy hired managers and contract milkers and the widespread adoption of once-a-dar milking.

\section{Introduction}

This paper shares some of our developing conceptual ideas on psychological contracts in dairy farming from a more interactional perspective, which will inform our 'Once-a-Day' milking research project. Little previous rescarch on psychological contracts appears to have explored such an alternative perspective since Levinson. Price. Munden. Manddle and Solley's seminal Men. Management and Mental Health of 1963.'

\section{Contracts of Employment}

The employment relationship can be conceived of as having two components: the legal contract of service. which covers the legal relations between the employer and the employec: and the psychological contract. which covers the behavioural relations between the parties. The legal expectations of this relationship are observable and quantifiable outcomes, while the psychological expectations are invisible, but nonetheless real.

The psychological contract construct first appeared around 1960. It was based on social contract and social exchange theories, and the idea of reciprocity (Rochling, 1997). Levinson et al. defined it as follows:

"The peschological contract is a series of mutual expectations of which the parties to the relationship mat not themselves be even dimly curare but which nonetheless govern

\section{their relationship to each other. "(Levinson} et al. 1963: 21).

Research on psychological contracts (Tipples and Verry, 2006) has either been largely survey based, particularly researchers following the lead provided in America by Denise Rousseau and colleagues, or based on critical incidents as initiated by Peter Herriot and colleagues in Britain. From the earliest research there has been a focus on the multi-facetted advantages of the construct. Levinson et al. (1963) distinguished managers' roles as preventive agents, diagnostic agents, remedial agents, and iatrogenic agents ${ }^{3}$ and promoted the psychological contract as a helpful managerial tool. Later Lorsch advocated the psychological contract construct and highlighted its diagnostic and therapeutic uses for managers (Lorsch, 1979). By September 2006 some 2680 publications on psychological contracts were listed in a search of the term on Google Scholar. From an overview of those papers Tipples and Verry (2006) recently suggested that useful guidance for managers is offered by some of the earlier research on the subject (c.g. by Levinson et al. 1963), as we seek to understand employment relationships. Such research focuses more on expectations than current researchers' fixation on the more transactional aspects of contracts, obligations and what the employec alone believes. It picks up on the need focused facets of psychological contracts, originally highlighted by Levinson et al. (1963), recently reemphasised by Meckler. Drake and Levinson (2003), and specifically distinguished from Rousseau's position by Conway and Briner (2005). 
A policy of 'Contracting' was recommended to employers and managers, especially of small businesses (Tipples, 1996). It suggested some practical ways of establishing and maintaining sound and on-going mutually matching employment relationships. This 'Contracting' strategy has four stages: Pre-creation, Creation, Maintenance and Termination. Its focus is on realism (Realistic Job Previews, Realistic Recruitment and Regular Re-Negotiation), for the sustainable management of staff. These are all personnel practices quite within the capability of the typical small enterprise manager. The central aim is to achieve better matches of expectations between employers and employees, to give more job satisfaction, more individual productivity, less labour turnover (Kotter, 1973), and to avoid unnecessary surprises disrupting the congruence of expectations between the parties. In practice it has been used to assist in resolving dairy farming employment problems (Tipples, Hoogeveen and Gould, 2000).

\section{A More Psychological View of Psychological Contracts}

In both cases the underlying, but desirable result is to create safety - Financial, Social, Physical, and Emotional safety. With emotional and functional safety the maximum energy goes into job performance, and there is the minimum need for defending and protecting self.

This is called emotional job fitness (Altdorfer, 1977). The Organizational Development literature (e.g. Roberts. 1977) suggests that this should be the ultimate end of successful contracting.

Good contracting leads to safety for both the employer and employee parties. When people feel safe they do not feel the need to defend themselves. When they feel 'safe' the parties function as autonomous adults, and they can:

- Concentrate on the task at hand, focus, and make fewer mistakes.

- Ask for help, advice, admit mistakes, and apologize when needed.

- Value themselves, be assertive, and take care of their own needs.

- Value others by communicating honestly at adult level.

- Think, feel, and do things in accord with their authentic self rather than play games.

Bad contracting leads to misunderstanding, defensiveness, stress and playing social and psychological 'games' (see Berne, 1964). When people do not feel safe they have to defend themselves. There are only three ways of doing this by fighting, fleeing, or negotiating

Fighting may be directly confrontational, i.e. there will be a winner and a loser. Someone is likely to get hurt and a great deal of non-productive energy will be spent. At best, fighting is energy and time consuming and likely to escalate. Fleeing may be overt - by literally leaving the arena, going away, leaving the job, or covert - by disguising the departure. Disguised departure includes day-dreaming, using chemical substances (see Bills, 2003), working 'by the book', or marking time (pretending to work). In extreme cases, suicide and escaping into madness are possible. Negotiating is an attempt to reason with the other party, i.e. an attempt to re-establish a psychological contract. If it is succeeds some degree of 'safety' can be achieved.

Given a sense that danger exists, the choice of strategy (fighting, fleeing or negotiating) will be determined by:

- Context - if the individual perceives himself/herself as being part of a like minded group, he/she may choose to fight or negotiate rather than leave.

- A sense of personal power or strong conviction.

- Knowledge and experience, a history of previous encounters.

- Personality and personal drivers.

\section{How Can Good Psychological Contracts be Achieved?}

It is important to understand that all human beings have two sets of needs: for stimulation and for structure. In many ways these needs are contradictory, shifting dynamically from and towards the poles:

Structure/Engulfment/Total safety $\leftarrow$ Healthy zone $\rightarrow$ Stimulus/Freedom/Abandonment

Each individual needs to find a 'healthy zone' somewhere between the extremes. Over-stimulation is the same as structure-hunger. Over-structure is in the same as stimulus-hunger. One important aspect for an employer is to establish exactly what mix of structure and stimulus an employee requires to be productive and to grow. Burnout is defined as an excess of both structure and stimulus. This leads to a very high loss of energy and a feeling of entrapment. This is very common and very destructive because it destroys both the personal safety and the excitement of being alive in the individual. (Roberts, 1993)

Communication is the basis of all psychological contracting. It is achieved by:

- Observing the other and responding to the other non-verbally;

- By interacting verbally. This means actually talking to each other - saying things, asking questions, listening to what the other says;

- Sharing tasks and working together. 
As Kotter (1973) suggested in the early days of psychological contract research, the greater the amount of thinking about the expectations, the more open discussion between the parties, and the more mutual understanding of their expectations, the greater the degree of matching of those expectations and the consequent increases in job satisfaction, productivity and longevity.

Until relatively recently there was little empirical research on psychological contracts (see Tipples, 1996. endnote 4). The difficulty of conducting empirical research may be attributed to the fact that the psychological contract is dynamic and that 'At any one point in time we can take a snapshot of the contract, but that's merely a fix on a moving target.' (Herriot, 1992, 7). Individuals may also have a number of psychological contracts at the same time (e.g. number of work roles occupied?).

Nevertheless, to help managers with real employment problems it is absolutely vital that they have staffing polices with a good research foundation. Pfeffer and Sutton (2006) have recently highlighted how managers have often failed because their policies were not research informed. The New Zealand dairy farming industry is too significant nationally for such problems to be allowed to compromise its future economic success.

\section{Employment Relations in Dairy Farming}

Dairy farming is a major part of the New Zealand economy. Overall agriculture is New Zealand's largest export earner. In the year to June 2004 it earned 53 pereent of New Zealand's total merchandise export value. Dairy exports alone were 21 percent of total merchandise export value. Dairy export value in 2004 was \$NZ 5.71 billion. which is projected to increase to $\$ N Z 6.86$ billion in 2008 as a result of higher volumes and prices (MAF. 2006). These were produced by 3.9 million cows in 12.751 herds (Fonterra, 2005).

In the five yearly 2001 Census of Population and Dwellings 35.037 people worked in the dairy industry but only 26,331 said it was their main job as dairy farmers or dairy farm staff. That number had fallen to this level from 29.964 in 1996 (Tipples, Wilson, Edkins and Sun. 2004). Over the last 20 years the number of dairy farms has been decreasing but they have been becoming larger. There are now fewer small herds and more large ones. Stocking rates have become more intensive. As a consequence the occupational structure of dairy farming has been changing. With larger, more complex farms/herds, more staff are needed and therefore more staff management skills. Traditionally dairy farming, particularly in the North Island, was an occupation dominated by the self-employed without employees, whether owners or sharemilkers.

Recently the numbers of self-employed dairy farmers without employees has been declining relatively and the numbers of employers and paid employees has been increasing. There has also been a profound aging of the dairy farming population, with the relative share of the population aged less than 35-39 decreasing and that aged more than 45 increasing. The self employed dairy farmer has been good at self-exploitation, working very long hours to do the work. With the increase in the number of employees, there has been no diminution in the long hours worked. The numbers working over 60 hours per week has been increasing over the last three censuses (1991, 1996 and 2001). However, educationally the dairy labour force is not well equipped to confront the structural changes the industry has been experiencing. It is less well educated than the population at large, except for having a slightly higher rate of vocational qualifications (Tipples et al., 2004). Nevertheless, dairy farming is still very much a lifestyle choice that impacts on the lives of all concerned.

\section{The Dairy Farming Ladder}

In the past, particularly during periods of high unemployment, dairy farming has provided an employment opportunity for those strongly financially motivated. The 'dairy farming ladder' allowed the farm worker/milker to advance through share milking to eventual property ownership. That prospect today appears less and less attractive to entrants to the industry and financially more and more unrealistic. Also, there are now more high level employment opportunities as herd and dairy farm managers, on good salaries, without the worries of being as heavily mortgaged as sharemilkers. Those employment opportunities are most evident in nontraditional South Island dairy farming areas such as Canterbury, where many extensive pastoral farms have been converted to large intensive dairy farms, with the aid of irrigation. Many dairy farmers and their staff have immigrated into Canterbury from other parts of New Zealand, but such numbers are insufficient to meet the employment needs of the industry (Tipples and Wilson, 2005). The use of overseas immigrants has helped alleviate this employment problem, but retaining dairy farm staff is still problematic. The situation has not been helped by the lowest levels of unemployment in New Zealand for over thirty years (Tipples et al., 2004).

The dairy farming industry has a vision of being the 'World's best in dairying' and its purpose is: "To enhance the sustainable competitive advantage of New Zealand dairy farming". Sustainability is expressed in an imperative to: "Increase the efficient use of resources, reduce reliance on non-renewable resources, and minimise negative impacts on the environment". Social sustainability is not mentioned expressly but it appears by implication in another imperative: "Be an attractive career prospect for current and potential farmers" (Strategic Framework for Dairy Farming's Future, 2005). However. whether the industry will continue to be socially sustainable is an open question. As an area of traditional family business it is disturbing to find that while only 30 pereent of family businesses survive to a second generation, some studies report succession rates as low as six percent for dairy farming (Lockhart and Reid, 2005) - perhaps an indication of an increasingly unacceptable lifestyle, and dairy farming no longer being an attractive career prospect. 


\section{The Dairy Farm Labour Crisis}

Staff shortages have dominated dairy farming news since the late 1990s, with problems being particularly acute in relatively 'new' dairy farming areas such as the irrigated parts of Canterbury, Otago and Southland. The dairy farming industry has been proactive in promoting dairy farming as both a career and a lifestyle (e.g. the Windows to Dairying, Let's talk Dairying programmes), but it has failed to recognise that it has some major problems. In the past the sector has been renowned for bad employment relations and low pay (Tipples, 1987; 1995). The latter has had to be addressed to ensure cows have been milked but the cash nexus is not a good basis for ongoing employment relations. If more cash was going to save dairy employers from their staff shortages the problems would have been solved long ago, but they have not. These difficulties have not been recognised by the industry, which has tended to veer away from any employees' perspective on the employment issues of the sector. For example, in 1994 Fairweather suggested that research he had carried out for the New Zealand Large Herds Association, which was based on a study of large herds' dairy farmers, should be complemented by a similar study of the views of dairy farm employees. That suggestion was never taken up. Perhaps if it had there would not have been the problems of finding sufficient staff that exist ten years later. Tipples, Hoogeveen and Gould began to explore this issue in a limited way from 1997 in studies of psychological contracts of dairy farming employers and employees (Tipples, Hoogeveen and Gould, 2000). They concluded that the two most important areas of difficulty were in the 'Time environment' and the 'General work environment'. Employers should be concerned particularly about the hours worked and the time-off given. These were the greatest areas of concern, yet the Census the following year showed that the hours of work were actually increasing (Tipples et al. 2004)!

With the shift in the dairy farm labour market in favour of employees there has been a shift in employer power. 'Good' employers (e.g. fair, concerned, involved, and even tempered) have little trouble getting staff. 'Bad' employers (e.g. bad tempered, unfair, exploitative, or unconcerned) have more and more difficulty getting staff (Verwoerd and Tipples, 2004). Now they have to take what they can get! In Canterbury dairy farming has had acute difficulties in recruiting/retaining staff. There have been no collective employment relations in dairy farming since the Employment Contracts Act 1991 to support the position of employees. Psychological contracts in Canterbury dairy farming have been studied through Herriot's 'critical incident' technique, which was applied to dairy farm employers/managers and employees to expose their psychological contracts. It showed that most incidents were in the areas of the environment in which work was carried out (e.g. the workplace itself, and associated staff housing) and more than half related to issues of time (e.g. very long hours, inappropriate rosters, and holidays). These were highlighted with employers as topics to concentrate on when recruiting staff. Employees' good treatment of the employers' property and animals was the most salient expectation of employees (Tipples, Hoogeveen and Gould, 2000).

Reducing the tyranny of long hours in the dairy farming industry has been a major concern since the rates of recruitment and retention in Canterbury have been so low. Ironically the system change which could alleviate these problems may have already been used by some farmers for several years. It is called 'Once-a-Day' milking (OAD) to distinguish it from the regular practice of the industry of 'Twice-a-Day' milking (TAD) (Searle, 2004). The notion of Once-a-Day milking as a viable dairy farming strategy has been known about as an expedient for periods of feed shortage for over twenty years, but other innovative farmers have used OAD for their whole herd at least since 1986/87. Since then, the implications of OAD milking have been researched from production, animal health and process engineering points of view (Bewsell, 2005). Virtually all published research has dealt with financial effects, with only passing reference to supposed personal benefits, and very little has been done or said about the possible effects of OAD milking on the lives of dairy farmers and their staff, and the families concerned. One student study considered changes to work organisation, farm management, family and lifestyle (Robert, 2003), before AgResearch were contracted by Dexcel to investigate the barriers to dairy farmers taking up OAD milking (Bewsell, 2005).

In 2002 there were fewer than ten farmers milking OAD all season on a long term basis (Bayly, 2002). In 2003 there were something under 30 (Searle, 2004), but by 2004 that had increased to 130 farms and by 2005 to 351 farms (Bewsell, 2005). With less than 5 percent of farms milking $\mathrm{OAD}$ at present, the impact of the change to $\mathrm{OAD}$ is not yet very clear. Finding good staff is an ongoing problem for dairy farmers. This has been cited as one of the major strategic concerns facing farmers and constraining productivity and expansion (Searle, 2003). Any initiative that may create an attractive incentive to accept employment, or impact on employment relations, is therefore of interest.

\section{Future Research}

To achieve the best results from our study we need to capture the essence of actual employment relationships, both legal and psychological. Our initial research tended to be quite anecdotal. Therefore we plan to make our findings as robust as possible, with a triangulation of research methods and sources of data. To that end we want to incorporate a number of non-verbal research methods into our technical armoury to overcome the issues of subjects' communication skills and being 'overresearched'

\section{Note}

I This research was funded by Dairy Farmers through Dairy InSight. 
When we began to think about a paper for the Twelfth Labour, Employment and Work conference it had been our intention to outline our findings on the initial employment aspects of 'Once-a-Day' milking. However, since our small, initial project had escalated into quite a large undertaking, it was no longer appropriate to report on those initial findings. We will report after completion of the substantive project towards the end of next year.

Iatrogenic is a medical term which refers to symptoms or illnesses caused by the physician himself in the course of his treatment of the patient

\section{Reference}

Altdorfer, O. (1977). Emotional Job Fitness. California: Courtney Davis

Bayly, A. (2002). The Profitability of Milking Cows Once-A-Day all Season in New Zealand. Kellogg Rural Leadership Programme Report. Lincoln: Lincoln University.

Bewsell, D. (2005). Adoption of Once-a-Da! Milking. Dexcel Report. AgResearch New Zealand.

Bills, J. (2003). Keeping your team healthy. In The Smart SIDE. SIDE Conference Proceedings. Lincoln: Lincoln University.

Conway, N.C. and Briner, R.B. (2005). Understanding Psichological Contracts at Work - A Critical Evaluation of Theory and Research. Oxford.

Fairweather, J. (1994). Social Organisation of Large Herds Dairy Farms in Ner Zealand. Research Report no. 222. Lincoln: Agribusiness and Economics Research Unit, Lincoln University.

Fonterra (2005). Dairying in New Zealand. Online: www.Fonterra.com

Kotter, J.P. (1973). The psychological contract: Managing the joining-up process. California Management Review, XV(3), 91-99.

Levinson, H., Price, C.R., Munden, K.J. and Solley C.M. (1962). Men. Management and Mental Health. Cambridge, MA: Harvard University Press.

Lockhart, J. and Reid, D. (2005). Success with succession: Creating a future for your family business. South Island Dairy Event Proceedings. 20-22 June, Lincoln: Lincoln University.

Meckler, M., Drake, B.H. and Levinson, H. (2003). Putting psychology back into psychological contracts. Journal of Management Enquir?, 12(3), 217-228.
Ministry of Agriculture and Forestry (2006). Situation and Outlook for New Zealand Agriculture and Forestry - Expectations for 2006 to 2010. July 2006 Update. Wellington: Ministry of Agriculture and Forestry.

Pfeffer, J. and Sutton, R. (2006). Hard Facts, Dangerous Half-Truths and Total Nonsense. Cambridge, MA: Harvard Business School Press.

Robert, A. (2003). Personal communication, via Professor Colin Holmes, Massey University.

Roberts, D.L. (1993). Training Seminar: Organisational Development. London: Metanoia Institute.

Roehling, M.V. (1997). The origins and early development of the psychological contract construct. Journal of Management History, 3(2), 204-303.

Searle, G. (2003). Where our future farm staff are coming from? South Island Dairy Event Proceedings. 23-25 June, Lincoln: Lincoln University.

Tipples, R.S. (1987). Labour relations in New Zealand agriculture. Sociologia Ruralis, XXVII(1), 38-54.

Tipples, R.S. (1995). The re-regulation of farming employment relations in New Zealand. Sociologia Ruralis, XXXV(1), 93-109.

Tipples, R.S., Hoogeveen, M. and Gould, E. (2000). Getting employment relationships right. Primary Industry Management, 3(2), 23-26.

Tipples, R.S. and Verry, J. (2006). How to manage staff with individual contracts? Some experiences with psychological contracts in New Zealand. $3^{\text {rd }}$ International Conference on Contemporary Business. Peppers Fairmont Resort, Leura, Blue Mountains, NSW, Australia. Hosted by Charles Sturt University, Faculty of Commerce.

Tipples, R.S., Wilson, J., Edkins, R. and Xiaomeng Sun (2005). Future dairy farm employment in New Zealand - An application of the human capability framework. Employment Relations, 5(1), 27-40.

Tipples, R.S. and Wilson, J. (2005). The dairy farming population and migrations. Primary Industry Management, 8(1), 41- 45 .

Verwoerd, N. (2005). Foreign workers on dairy farms. In Proceedings of the SIDE Conference 2005. Lincoln: Lincoln University.

Verwoerd, N. and Tipples, R.S. (2004). Dairy Farmers as Employers in Canterbury. FHMG Research Report 01/2004, Lincoln: Lincoln University. 


\section{Authors}

Rupert Tipples

Senior Lecturer

Agriculture and Life Sciences Division

Lincoln University

P.O. Box 84

Lincoln 7647

Canterbury

Tipplesr@lincoln.ac.nz

\section{Nona Verwoerd}

Independent Consultant and Researcher nonav@bigfoot.com 